\title{
Basic Education EFL Majors' Listening Skills: An Evaluative Study
}

Abdullah Mahmoud Ismail ${ }^{1}$, Hussein Taha $\mathrm{Atta}^{2}$, Ahmed Sabet Abu-El wafa Ali $^{3}$

${ }^{1}$ Professor of Curricula \& EFL Methodology, Faculty of Education, Sohag University, Sohag, Egypt.

${ }^{2}$ Professor of Curricula \& FFL Methodology, Faculty of Education, Sohag University, Sohag, Egypt.

${ }^{3}$ Demonstrator of Curricula \& FFL Methodology, Sohag Faculty of Education Sohag University, Sohag, Egypt.

DOI:

\begin{abstract}
The current study aimed to evaluate EFL students' listening skills. Therefore, a test of listening comprehension skills was designed to evaluate the listening performance of the third-year students of the Basic Education section. Forty third-year Basic Education students at Sohag Faculty of Education participated in the study. In addition, students' and instructors' perspectives were surveyed using structured interviews. The results of the study showed that EFL Basic Education students had numerous problems when it comes to their listening performance. In general, most of the interviewed instructors and students indicated that Basic Education students suffer from numerous symptoms of listening comprehension failure in foreign language learning settings. This affected not only their performance in language settings but also their overall academic performance. Based on these findings, a set of recommendations and suggestions were provided to foreign language instructors, text designers, and program developers.
\end{abstract}

Key words: An Evaluative Study, Listening Skills, Basic Education EFL Majors.

\section{Introduction}

Listening is a core component in the language education programs that should receive due attention. There is a need to qualify learners for future careers in diversified workspaces and places. As stated by Bress (2006), listening must surely be the most practiced of all four language skills. The more students understand the more they would feel confident. This, in turn, enhances their overall performance and improves their language proficiency levels. Listening comprehension is important for language learning generally and for foreign language instruction in particular. As expressed by Brown (2001), effective language learning cannot occur without sufficient language input. Listening is an avenue for such input.

Empirical research associates effective listening performance with better gains in a wide range of learning-related variables. For example, quality listening performance had a positive impact on individuals' self-efficacy and positive self-image (Siew \& Wong 2005). As well, effective listening performance resulted in lower levels of foreign language classroom anxiety (Magogwe \& Oliver 
2007; Serraj \& Rourdin 2013). Similarly, Kassem (2015) associated the effective use of listening strategies by Egyptian EFL college students with higher levels of comprehension and more sophisticated self-efficacy beliefs.

Yet, despite being a core component in most language programs, listening instruction, according to Archer (2003) is the least emphasized, and listening as a language skill is mostly neglected in most language classrooms. This might be due to numerous reasons. For example, as stated by Chamot (2005), listening is so difficult to describe being a covert activity that cannot be easily explored. Another reason lies in the false assumption that listening is developed naturally (Sadighi \& Zare 2006), which in turn results in scarcity of research in this regard.

The research literature on listening instruction has voiced numerous problems that make it urgent that educators and language researchers to search for new alternative pedagogies and instructional practices to handle such problems. These problems are common to most educational settings of foreign language instruction worldwide; the Egyptian context is no exception.

Doff and Christopher (2004), Sharma (2006), and Piolat (2008) have all outlined problems that students often encounter in listening settings in various FL contexts. These include such problems as the limited vocabulary knowledge base and inability to catch up with speedy delivery of listening materials characteristic of native speakers' performance that is often beyond students' control. Goh (2000) attributed part of the listening difficulty that most EFL students face to cognitive factors. Students are often unable to activate requisite cognitive capabilities to handle listening selections. Pilot (2008) sees that the cognitive effort exerted by students is quite instrumental in enhancing their fluency in foreign language settings. Lang and Ross (2009) agree that among the four language skills, listening is the most difficult for learners as it requires on-the-spot cognitive processing of numerous variables, including linguistic, communicative, contextual, and intellectual variables.

These problems are common in listening contexts world-wide. For example, Song (2008) concluded that foreign language students often have difficulty handling listening tasks in an effective way due to inadequacy of listening strategies they were able to deploy. Nunan (2003) cited many issues in listening settings such as inappropriate teaching strategies, irrelevant and uninteresting content, boring instructional practices, to mention just a few. Similar problems were observed in the Turkish (Azmi \& others 2014), Indian (Sharma, 2007), as well as the Iranian contexts of FL instruction (Sadighi \& Zare 2006).

The Egyptian context of foreign language instruction echoes similar problems. For example, Ghoneim (2013) found that Egyptian EFL students have difficulty in understanding listening comprehension passages. Students attributed their problems to the absence of training in listening strategies. This problem seems to be prevailing at different levels of schooling along the Egyptian 
educational ladder. For example, Ahmed (2014) and Hassan (2015) cited problems in listening with primary students. Abo Elkassem (2009) and Al-ammary (2015) cited listening problems with students at the preparatory stage. Similar problems were cited at the secondary stage (Genaidy 2011; Amin 2012) as well as at the college levels of foreign language education (Salem 2014).

Problems at the college level constitute a real concern as those students have reached the highest formal educational level and should therefore have achieved mastery of requisite skills thereof. The problem extricates with EFL studentteachers whose abilities or absence thereof will carry over to their future EFL students. Unless those instructors are equipped with requisite skills, strategies, and instructional best practices, this will carry over to students, resulting in a repeated cycle of dysfunction in foreign language settings.

\section{Statement of the Problem}

Based on the survey of the literature outlined above, and the assessment of students, it is clear that EFL students suffer from poor performance in some listening skills such as, guessing the meaning of unfamiliar words from the listening context, extracting specific information from listening selections, making inferences, identifying the main idea in the spoken discourse, recognizing the speaker's attitudes and opinions, identifying functions in conversations, recognizing lexical chunks and idioms, following details without being distracted.

Based on the previous related studies, it is observed that listening instruction has numerous problems that make it urgent that educators and language researchers search for new alternative pedagogies and instructional practices to handle such problems. In summary, it is very important for us to conduct listening skills evaluation to ensure that they can effectively facilitate the attainment of teaching process, and at the same time, be economically beneficial to instructors and students.

\section{Question of the Study}

The study attempted to answer the following question:

"How far do EFL Basic Education students master the requisite listening skills?"

\section{Delimitations of Study}

The current study was delimited to the following:

1. A sample of Basic Education students at Sohag Faculty of Education. Those students suffer from numerous language problems that should be duly taken care of lest these problems carry over to their future students.

2. A list of some listening skills, including guessing the meaning of unfamiliar words from the listening context, extracting specific information listening selections, making inferences, identifying the main idea in the spoken discourse, recognizing the speaker's attitudes and opinions, identifying functions 
in conversations, recognizing lexical chunks and idioms, following details without being distracted. These skills, as stated in the literature surveyed before, constitute core components of students' listening performance.

\section{Review of Literature}

As stated by Abbas (2016), listening is one of the most important skills in English language learning. Rost (2002) defined listening as a complex process of interpretation in which listeners match what they hear with what they already know. According to Rost (2009), listening helps students to understand the world around them and is one of the necessary elements in creating successful communication. Jafari and Hashim (2015) emphasized that listening is a channel for comprehensible input, and more than 50 percent of the time learners spend in learning foreign languages was devoted to listening. Pham (2017) asserted that listening is one of the most necessary skills to communicate in real life. Everybody knows to listen to a message is not as simple as hearing it, so the listener has to understand the message and respond in the right manner.

Listening is one of the most important communication skills and listening is an active process that requires attention. Communication is not complete without effective listening. An attentive listener stimulates better speaking by the speaker. Shahbaz (2014) stated that effective listening is the process of analyzing sounds, organizing into recognizable patterns, interpreting the patterns, and understanding the message by inferring the meaning. According to Vandergrift (2003) "It is a complex, active process in which the listener must discriminate between sounds, understand vocabulary and grammatical structures, interpret stress and intonation, construct meaning from the spoken words, and relate what they hear to existing knowledge involves a great deal of mental activity on the part of the listener"(P. 168).

According to that interactive nature of listening, the listener receives the sound waves through the ear and then acts on them, making use of cognitive and affective mechanisms (Brown 2010). It also requires much effort and practice from the students (El-Sagheer \& Leviene 2002). Yang (2005) adds "To do well in listening, the listeners must have sufficient knowledge of the language" (P. 33). Moreover, Steinberg (2007) explained that listening is more complex than merely hearing. It is a process that consists of four stages: sensing and attending, understanding and interpreting, remembering, and responding. Further, Caldwell (2008) asserted that comprehension is an unobservable process that is extremely complicated and multifaceted in entity. So, he defined listening as "the process of simultaneously extracting and constructing meaning through interaction with oral language" (P. 2). Additionally, Nordquist (2014) stated that listening is an active process of receiving and responding to spoken (and sometimes unspoken) messages. 
Listening is assumed to have a more and more important place in foreign language teaching and learning processes. Listening is considered one of the most essential skills for both communication and language learning. At the same time, its facilities the emergence of other language skills: speaking, reading, and writing. It is often used together with other language skills. It is not only a skill area in language performance but also a critical means of acquiring a second language. It helps students to acquire good speaking habits as a result of the spoken English they have absorbed and helps them to improve their pronunciation. Listening texts often provide excellent examples of speaking functions. Additionally, El-Sagheer and Leviene (2002) mentioned that listening to comprehensible input can aid language acquisition. As such, listening is considered the channel through which language is naturally acquired.

There are many differences between hearing and listening skills. Gutierrez-Ang (2009) summarizes those differences as follows: hearing is a physical process; natural; passive; listening is a physical; mental process; active; learned process. As a skill, hearing is the first stage of listening. The process of listening is understanding, learning, remembering, recalling, receiving, hearing, responding, answering, evaluating, and judging. Third (2019) stated that the most valuable skill for positively influencing others is active listening. Listening is a skill that is difficult to master and requires practice. However, it is worth the effort.
As stated by Ciano (2014), listening is often confused with hearing. While hearing is a biological process that can be scientifically explained, listening is a neurological cognitive regarding the processing of auditory stimuli received by the auditory system. Similarly, Barthes (2014) distinguished between hearing and listening, stating, Hearing is a physiological phenomenon while listening is a psychological act. Barthes also states that listening could be defined as an intentional act of audition. Hearing is always occurring, most of the time subconsciously. Listening is the interpretative action taken by the listener to understand and potentially make meaning out of the sound waves. Listening can be understood on three levels: alerting, deciphering, and understanding of how the sound is produced and how the sound affects the listener.

As outlined by Holmes (2019), active listening is a complicated process involving a set of interrelated process. It starts with individuals getting interested in listening to a given message, followed by involvement in the process through responding to delivered message. To stay on target, individuals need to test their understanding and critique received ideas and implications. Details are provided in fig (3).

As stated by Richard and Nordquist (2020), listening is the active process of receiving and responding to spoken (and sometimes unspoken) messages. It is one of the subjects studied in the field of language arts and the discipline of conversation analysis. Listening is not just 
hearing what the other party in the conversation has to say. Baumeyer (2014) stated that effective listening means hearing the message being sent, making meaning of it, and responding in a way that the sender knows you truly understand.

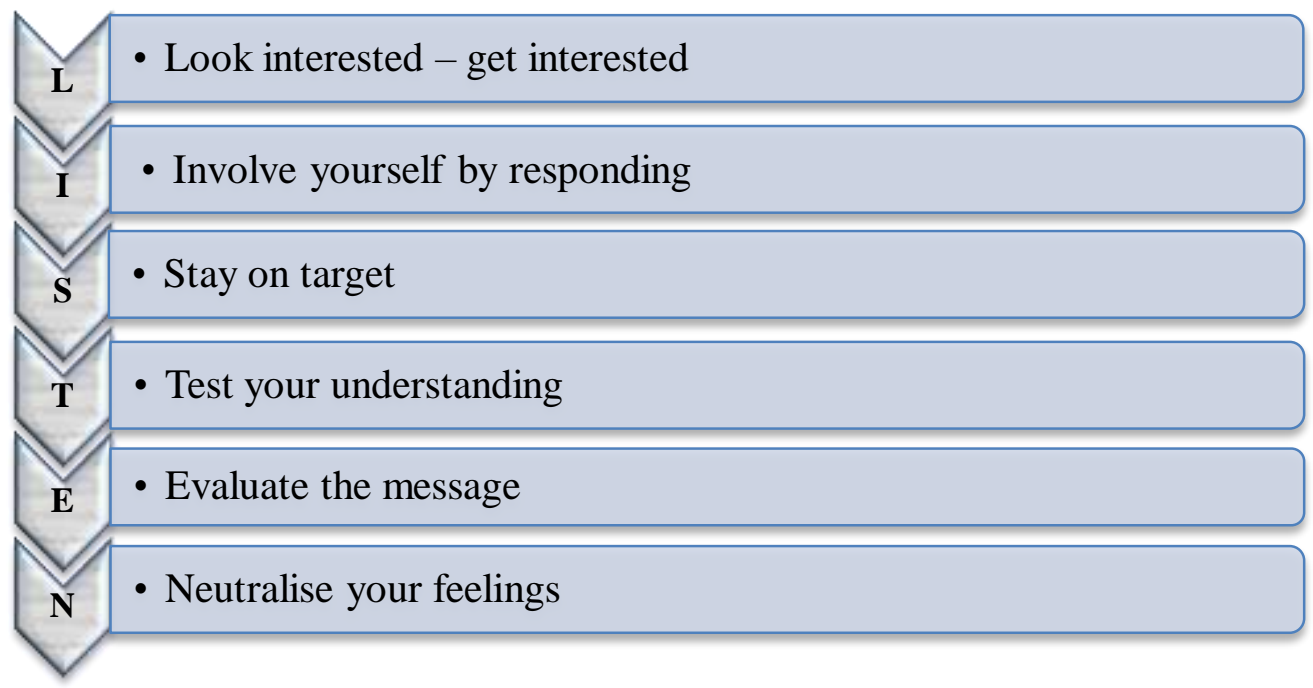

Fig (3): Active listening (Christopher Holmes 2019)

Sebongbong (2019) asserted that listening is the act of hearing attentively and showed that $45 \%$ of our time is spent on listening. Students listen more than speak. If the listening skill is used properly, they can master the tools of communication skills. Listening is difficult, as the human mind tends to distract easily. A person who controls his mind and listens attentively acquires various other skills and is benefited. Usman (2015) stated that the word listen refers to making an effort to hear something or pay attention to someone speaking or to some specific sound. As expressed by Moulesong (2010), hearing is the physical ability, while listening is a skill. Listening skills allow one to make sense and understand what another person is saying. In other words, listening skills allow people to understand what someone is talking about the meaning behind the words.
As stated by Anderson (2018), active listening can help hugely but it does require you to listen, and act! The most difficult part of that is the 'act' part but it can have and make a huge difference. Listening carefully to colleagues, even if it is on a topic where there is some negativity and then acting on it, shows that you do listen! It's a skill that is difficult to master, get right, and to turn that negativity from a colleague into positivity.

Mulvania (2019) declared that listening is essential to communicating respect for another person. To test this claim, reflect on your feelings. Consider a time when one may have been talking with someone who interrupted him/her or continually focused on what they wanted to express in the conversation. Maybe it was clear that their mind was elsewhere, and they weren't at all "fully present" with what is said. When one wants to build a strong relationship with another person, ability and commitment to listening 
attentively and empathically are essential. Beqiri (2017) reminded that listening is an important part of communication being able to actively listen is an important communication skill. It's easily overlooked, as people tend to focus more on what they want to say, rather than listening to what the other person is saying. Knowing when to pause to allow the other person to talk is an important skill. It conveys respect and a willingness to hear the other person's point of view.

As stated by Barnarda (2017), listening skills can build relationships, solve problems, ensure understanding, and avoid conflict. By becoming a better listener, one will improve his/her workplace productivity, as well as ability to lead a team, persuade and negotiate. Various studies stress the importance of listening as a communication skill. The studies on average say that listeners spend $70-80 \%$ of their waking hours in some form of communication. Of that time, students spend about 9 percent writing, 16 percent reading, 30 percent speaking, and 45 percent listening. Studies also confirm that most of them are poor and inefficient listeners. Most of them are not very good at listening, so they remember less than $50 \%$ of what they hear in a conversation.

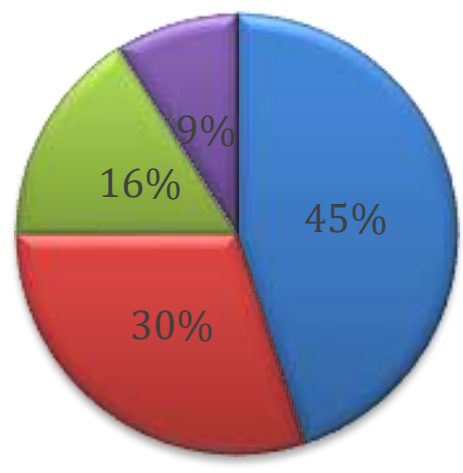

$\boldsymbol{\nabla}$ Listening $\boldsymbol{\nabla}$ Speaking $\boldsymbol{\nabla}$ Reading $\boldsymbol{\nabla}$ Writing

Fig (4): Time spent communicating in listening (Barnarda 2017)

Tiret (2015) emphasized that people are communicating with others when they are actively forming, in their minds, what they are going to say next after the other person stops talking. This takes their attention off the other person, and they tend to miss what they are saying. Listening involves more than just hearing, it also involves responding to what someone is saying. This process is called active listening. It's the key to all effective communication. without effective listening, messages are easily misunderstood. As confirmed by Wong (2014), 
listening is the key component of all effective communication. Without the ability to listen effectively, messages can be misunderstood or interpreted incorrectly. A communication breakdown may cause the sender to be irritated and frustrated. Maverick (2019) asserted that it's beneficial for students if they are good listeners. Among many benefits, also mentioned some of the key benefits of effective listening. It benefits both listener and speaker as well. The good listener can retain important aspects of the message:

1. It helps one to make decisions or to solve problems regarding the topic.

2. Effective listening helps one to develop a good relationship with the speaker.

3. It encourages both, the listener and the speaker, to share valuable experiences with each other.

4. When one effectively listens to his/her speaker, he/she feels encouraged. It motivates them to give their best.

Tyagi (2013) stated that listening skill is key to receiving messages effectively. It is a combination of hearing what another person says and psychological involvement with the person who is talking. Listening is a skill of language. It requires a desire to understand another human being, an attitude of respect and acceptance, and a willingness to open one's mind to try and see things from another's point of view. It requires a high level of concentration and energy. It demands that we set aside our thoughts and agendas, put ourselves in another's shoes, and try to see the world through that person's eyes.

Metruk (2019) stated that the four language skills (listening, reading, writing, and speaking) represent principal components of the command of a foreign language, but it is through the receptive skills, namely listening and reading that EFL learners are exposed to meaningful language so that they can develop their language abilities. This study attempts to fill in the gap by focusing on practicing listening skills of EFL learners by watching movies and TV programs in the original in English. the significance of listening skills in EFL teaching and learning is undeniable. EFL listening skill is regarded as a problematic language skill especially in a foreign language context where real practice chances are narrow (Nowrouzi \& others 2015). Teaching students listening skills may be difficult for teachers and namely difficult for students to learn as well. For instance, even the students who are adequate in speaking and reading might confront problems with listening skills when facing a record with a quick conversation (Ghaderpanahi 2012).

Ulum (2015) stated that listening skill is the weakest skill of EFL students who encounter different kinds of listening problems. It is the most underestimated skill in EFL context. As expressed by Taghinezhad (2015), listening has a significant role in language learning, yet it is still an area where students feel most disappointed and powerless. In Iran's English teaching, listening has been stressed for a long time; however, this skill stays poor for some learners 
even after they have had five to ten years of involvement in learning English. Both the mother tongue and foreign/second language teaching process consist of four basic language skills (reading, listening, speaking, and writing). One of the most important concerned language skills is also listening (Alyılmaz 2018).

According to Ünalan (2006), listening is the whole of the sounds that the person chooses and willingly perceives depending on his preference.

Melanlıoğlu (2013) considered listening in the communication process and defined this skill as meaning and react to the voices heard. According to Sever (2004), "listening can be defined as understanding what we hear and hiding or paying attention to what we hear" (P.10). The individual uses listening skills for the majority of his / her life (Tyagi 2013). In our schools, most of the instructors use the method of flat speech (declaration). In this case, the time that students devote to listening increases even more and they obtain almost $83 \%$ of what they learn through listening (Çifci 2001).

Listening skill is an important part of learning a language, which needs to be developed (Gilakjan \& Brownell 2016). As asserted by Pourgharib (2014), maintains that listening skill may be the single most important skill promoting personal and professional development since it influences the effectiveness of individuals, both at school and in the workplace, the listening skills are more important than other language skills (reading, writing, speaking) as it is the first acquired skill. In learning English, listening skill is considered as the essential skills among other skills (speaking, reading, and writing), but it involves a complex process. As listening is known as the most frustrating ability that ESL or EFL learners can master for the very first time, several problems have emerged (Al-azzemy \& Al-jamal 2019; Aryana and others 2018; Du 2019 and Emerick 2018). Take an example; learners are unable to regulate the aural input speed, which leads them to hear the sounds correctly. In other cases, even though the learners accurately capture the sounds, they sometimes experience some comprehension problems because they lack adequate knowledge of vocabulary, colloquial language, or even slang language (Hamouda 2013; Namaziandost \& others 2019; Vandergrift \& Goh 2012). Thus, learners need language input as much as possible. Ainin (2020) asserted that listening skills are an important part of communication and are the basis of second language learning or foreign languages. The essence of interaction ability is the ability to understand what others say. The purpose of this study is to describe the pattern of direct learning strategies used by students in listening to Arabic speech, describe the pattern of indirect learning strategies used by students in listening to Arabic speech, and describe student perceptions of the important learning strategies in developing listening skills.

\section{Method}

\section{Participants}

The sample of the study was drawn from amongst the population of third-year Basic Education 
students, at Sohag faculty of education. Their ages ranged from twenty to twenty-one years old. They all lived in Sohag with similar socio-cultural backgrounds. The study was concerned with those students being the prospective instructors of English whose competence or absence thereof would carry out over to their future students, thus constituting a cornerstone for the success or failure of English education at the primary stage.

\section{Design of the Study}

To achieve the aim of this study, the researcher adopted the descriptive approach. Such an adoption was due to the nature of the research, which aimed at discussing and evaluating the listening skills and the opinions of students and instructors about them. Forty students were randomly selected from amongst the population of third-year Basic Education English majors. According to Sandelowski (2000), the qualitative descriptive study is the method of choice when straight descriptions of phenomena are desired. Such study is especially useful for researchers wanting to know who, what, and where of events. Although foundational to all qualitative research approaches, qualitative descriptive studies comprise a valuable methodologic approach in and of themselves. Researchers can unashamedly name their method as qualitative description.

\section{Instruments of Study}

The researcher constructed the following instruments:

\section{The Listening Skills Test}

\section{Aim Test}

The test was designed to evaluate EFL students' listening skills. The test was used to indicate the student's mastering of listening comprehension skills.

\section{Test Description}

The test included twenty items targeting students' performance of the considered listening skills. Weights of respective skills and corresponding question items are detailed in the following table of specifications.

\section{Scoring Techniques}

The researcher prepared an analytic rubric to evaluate students' performance in the EFL listening skills test. Their answers on the test were scored out of (20) marks. One mark for each point.

\section{Test Validation}

To ensure the validity of the listening skills test, the researcher submitted the initial form to a jury of TEFL faculty members to decide on:

1. The suitability of the listening texts for student's level.

2. The suitability of the items to the listening skills of the test.

3. The appropriateness of the items to cover the identified skills considered.

4. The clarity of the test instructions.

The jury members appraised the test and its scoring rubrics as being valid, clearly stated, and suitable for the purpose they were designed. 
The selected listening selections were approved to be suitable for assessing students' listening skills. Yet, they suggested some modifications, such as designing a table of specifications for each test and restating some answers to the questions.

Table (1): Table of specifications of the listening test

\begin{tabular}{l|l|c|c|c}
\hline \multicolumn{1}{c|}{ Skills } & \multicolumn{1}{c|}{ Tasks } & $\begin{array}{c}\text { Items } \\
\text { mark }\end{array}$ & $\begin{array}{c}\text { Numbers } \\
\text { of test } \\
\text { items }\end{array}$ & $\begin{array}{c}\text { Relative } \\
\text { weight of } \\
\text { each skill }\end{array}$ \\
\hline $\begin{array}{l}\text { 1. Guessing the meaning of } \\
\text { unfamiliar words from the } \\
\text { listening context. }\end{array}$ & $\begin{array}{l}\text { Listen to the passage then guess the } \\
\text { meaning of unfamiliar words. }\end{array}$ & 1 & 4 & $16 \%$ \\
\hline $\begin{array}{l}\text { 2. Extracting specific } \\
\text { information from listening } \\
\text { selections. }\end{array}$ & $\begin{array}{l}\text { Listen to the passage then choose } \\
\text { what kind of information is probably } \\
\text { required to complete the meaning. }\end{array}$ & 1 & 2 & $11 \%$ \\
\hline $\begin{array}{l}\text { 3. Making inference. } \\
\text { fisten to the passage then choose } \\
\text { the suitable inference. }\end{array}$ & $\begin{array}{l}\text { Listen to the passage then choose } \\
\text { the main idea in the text. }\end{array}$ & 1 & 1 & $11 \%$ \\
\hline $\begin{array}{l}\text { 4. Selecting the main idea } \\
\text { from context. }\end{array}$ & $\begin{array}{l}\text { Listen to the passage then choose } \\
\text { the correct answer. }\end{array}$ & 1 & 3 & $14 \%$ \\
\hline $\begin{array}{l}\text { 5. Recognizing the speaker' } \\
\text { attitudes and opinions. }\end{array}$ & $\begin{array}{l}\text { Listen to this conversation then } \\
\text { answer the questions. }\end{array}$ & 1 & 2 & $11 \%$ \\
\hline $\begin{array}{l}\text { 6. Identifying functions in } \\
\text { conversations. }\end{array}$ & Choose the correct answer. & 1 & 3 & $14 \%$ \\
\hline $\begin{array}{l}\text { 7. Recognizing lexical } \\
\text { chunks and idioms. }\end{array}$ & $\begin{array}{l}\text { Listen to this passage then choose } \\
\text { "true" or "false". }\end{array}$ & 1 & 3 & $14 \%$ \\
\hline $\begin{array}{l}\text { 8. Following details without } \\
\text { being distracted. }\end{array}$ & $\mathbf{8 0}$ & $\mathbf{2 0}$ & $\mathbf{1 0 0 \%}$ \\
\hline
\end{tabular}

\section{Test Piloting}

After modifying the test according to the jury members 'comments, it was piloted on a randomly selected sample of 30 students from the third- year of Basic Education section, Sohag faculty of education to determine its duration, validity, and reliability.

\section{Test Duration}

Duration of the listening test was calculated by averaging the time needed by individual students to answer all test items. The calculated time was 25 minutes.

\section{Test Reliability}

The EFL listening skills test was administered to a randomly chosen sample of 30 third- year of the Basic Education section. The pilot study was conducted two weeks before the administration of the study. Correlation between students' total scores of the test in the two administrations was calculated using Pearson Product Moment correlation, which was estimated by IBM SPSS, 
Version 22.0. The researcher utilized the shown in tables (2) below.

Cronbach Alpha formula, and the results were

Table (2): Correlation between students' scores of the test - re-test method

\begin{tabular}{c|c|c|c|c|c}
\hline Applications & M & SD & Correlation & Cronbach Alpha & Sig. \\
\hline First & 12.66 & 1.20 & \multirow{2}{*}{0.837} & 0.901 & 0.01 \\
\cline { 1 - 3 } Second & 12.53 & 1.70 & & & \\
\hline
\end{tabular}

It is noted from the table that the test has a high degree of reliability, where the value of the reliability coefficient of re-test was $(0.837)$ and the value of the Alpha coefficient of reliability was $(0,901)$, was found to be significant at $(0$, 01) level, indicating that the test has an appropriate degree of reliability.

\section{Test Difficulty}

An analysis of students' responses to individual questions was conducted to determine the question's difficulty index of this test. The value of difficulty ranges from (0.33 to 0.70$)$. Thus, these values are very suitable and within an acceptable level (Haladyna \& others 2002).

Table (3): Difficulty indices of the listening test

\begin{tabular}{c|c|c|c}
\hline No & $\begin{array}{c}\text { Difficulty } \\
\text { indices }\end{array}$ & No & $\begin{array}{c}\text { Difficulty } \\
\text { indices }\end{array}$ \\
\hline Question (1) & .33 & Question (11) & .63 \\
\hline Question (2) & .67 & Question (12) & .33 \\
\hline Question (3) & .47 & Question (13) & .37 \\
\hline Question (4) & .70 & Question (14) & .33 \\
\hline Question (5) & .47 & Question (15) & .33 \\
\hline Question (6) & .60 & Question (16) & .43 \\
\hline Question (7) & .37 & Question (17) & .33 \\
\hline Question (8) & .47 & Question (18) & .53 \\
\hline Question (9) & .47 & Question (19) & .63 \\
\hline Question (10) & .40 & Question (20) & .53 \\
\hline
\end{tabular}

\section{A- Interpretation of values:}

.5 or less extremely easy

$.6-.10$ very easy

$.11-.20$ easy

$.20-.34$ moderately easy

.35- .64 about right for the average student

$.66-.80$ difficult

.81- .89 fairly difficult

$.90-.94$ very difficult

.95- 1 extremely difficult

\section{B- Computing difficulty index:}

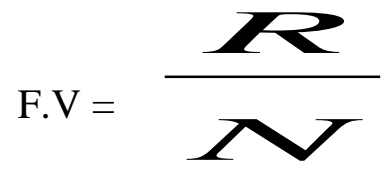

$\mathrm{F} . \mathrm{V}=$ difficulty value.

$\mathrm{R}=$ number of incorrect answers.

$\mathrm{N}=$ number of test items.

\section{Test Discrimination}

An analysis of students' responses was done to determine how well each item discriminates 
between high- and low-level achievers. According to Allam (2004), discrimination coefficients for the test items were calculated by using Kelly, who relies on the following steps:

- Order the scores of the students in descending order.

- Separate $27 \%$ of the scores of the sample, which is in the upper part and got the highest grades.
- Separate $27 \%$ of the scores of the sample, which is in the lower part and got the least grades.

Using "Johnson" Equation Discrimination Coefficients for the test items were ranged between (.53 to .93), which is considered high discrimination coefficients. The discrimination indices are very suitable and within an acceptable level.

Table (4): Discrimination indices of the listening test

\begin{tabular}{c|c|c|c}
\hline \multicolumn{1}{c|}{ No } & Disc indices & No & Disc indices \\
\hline Question (1) & .66 & Question (11) & .66 \\
\hline Question (2) & .60 & Question (12) & .86 \\
\hline Question (3) & .66 & Question (13) & .66 \\
\hline Question (4) & .53 & Question (14) & .53 \\
\hline Question (5) & .60 & Question (15) & .93 \\
\hline Question (6) & .60 & Question (16) & .86 \\
\hline Question (7) & .66 & Question (17) & .80 \\
\hline Question (8) & .66 & Question (18) & .80 \\
\hline Question (9) & .53 & Question (19) & .93 \\
\hline Question (10) & .60 & Question (20) & .60 \\
\hline
\end{tabular}

\section{A- Interpretation of values:}

.50 - above very good discrimination

$.30-.50$ adequate discrimination

$.20-.29$ weak discrimination

$0-.19$ very weak discrimination

-Ve questions probably invalid

\section{B- Computing discrimination index:}

$\mathbf{D}=\frac{\text { Correct } U-\text { Correct } L}{N}$

$\mathrm{D}=$ discrimination index .

$\mathrm{U}=$ Upper half of test items.

$\mathrm{L}=$ Lower half of test items.

\section{C- Pearson Product Moment}

\section{Correlation Formula}

$\mathbf{R}=$

$\frac{N(\Sigma X Y)-\Sigma X \quad \sum Y}{\sqrt{\left[N\left(\Sigma X^{2}\right)-(\Sigma X)^{2}\right]\left[N\left(\Sigma Y^{2}\right)-(\Sigma Y)^{2}\right]}}$

$\mathrm{R}=$ Pearson Product Moment Correlation .

$\mathrm{N}=$ Number of test items.

$\Sigma=$ Sum of.

$X=$ Raw scores of the first test.

$\mathrm{Y}=\mathrm{Raw}$ scores of the second test.

\section{Results}

In an attempt to examine the status quo of listening performance in foreign language settings of those EFL student-teachers in the 
Egyptian context, the researcher investigated their listening performance. In terms of their listening performance, the researcher administered a listening test to a random sample of EFL Basic Education students to investigate their level in the requisite listening skills. The listening test consisted of eight dimensions, including students' ability to extract specific information from listening selections, their ability to guess the meaning of unfamiliar words from the listening context, their ability to make inferences, their ability to identify main ideas in the spoken discourse, to recognize the speaker's attitudes and opinions, to recognize functions in conversations, to recognize lexical chunks and idioms, and their ability to follow details without being distracted. The results are shown in table (5).

Table (5): Results of the assessment of students' listening performance

\begin{tabular}{|c|c|c|c|c|}
\hline The listening skills & $\mathbf{N}$ & $\begin{array}{c}\text { Mean } \\
\text { out of } 20\end{array}$ & percentage & percentage \\
\hline $\begin{array}{l}\text { 1- Guessing the meaning of unfamiliar words from } \\
\text { the listening context. }\end{array}$ & \multirow{8}{*}{40} & 7.5 & $37.5 \%$ & $37.5 \%$ \\
\hline $\begin{array}{l}\text { 2- Extracting specific information from listening } \\
\text { selections. }\end{array}$ & & 6.5 & $32.5 \%$ & $32.5 \%$ \\
\hline 3-Making inferences. & & 5.5 & $27.5 \%$ & $27.5 \%$ \\
\hline 4-Identifying the main idea in the spoken discourse. & & 8 & $40 \%$ & $40 \%$ \\
\hline 5- Recognizing the speaker's attitudes and opinions. & & 7 & $35 \%$ & $35 \%$ \\
\hline 6- Identifying functions in conversations. & & 7.5 & $37.5 \%$ & $37.5 \%$ \\
\hline 7- Recognizing lexical chunks and idioms. & & 6.5 & $32.5 \%$ & $32.5 \%$ \\
\hline 8- Following details without being distracted. & & 5 & $25 \%$ & $25 \%$ \\
\hline
\end{tabular}

Results displayed in the above table indicate that EFL Basic Education students had numerous problems when it comes to their listening performance. $(67.5 \%)$ of the sample had problems in listening to extract specific information from listening selections. (62.5\%) of students showed weakness in listening to guess the meaning of unfamiliar words from the listening context. Similar weaknesses have been displayed in making inferences from listening selections $(72.5 \%)$, identifying the main idea in the spoken discourse $(60 \%)$, recognizing the speaker's attitudes and opinions (65\%), Identifying functions in conversations (62.5), recognizing lexical chunks and idioms (67.5\%) and following details without being distracted $(75 \%)$.

These listening problems were not all due to linguistic variables but seemed to have stemmed from other non-linguistic variables such as intellectual and thinking abilities. Research indicated that the latter category had a significant 
impact on the listening performance of EFL students. For example, Ghoneim (2013) attributed poor listening performance to the inability to deploy higher order thinking strategies in different listening settings. These include such strategies as making predictions, testing hypotheses, activating background knowledge in listening settings, interpreting clues, connecting, and associating.

To decide on the current problem, the researcher conducted an evaluative study of listening skills for third-year Basic Education students. Both the listening skills as well as the employed activities and instructional procedures were evaluated. The researcher then held an interview with EFL students and instructors as a qualitative research method that relied on the interaction between the researcher and participants. The interview aimed at identifying students' listening skills. Thus, EFL students were asked about their perceptions, opinions, beliefs, and attitudes towards their listening skills. The interview was employed in the study as a qualitative method for collecting objective data from some EFL instructors and students. In interactive group setting, participants were free to talk with other group members.

Table (6) The listening skills' interview of EFL students and instructors

\section{Statements}

1. The specialize curriculums helped you to listen well.

2. The listening skills involved in your curriculums were appropriately taught.

3. The listening skills involved in your curriculums were appropriate to your needs.

4. The listening skills involved in your curriculums were satisfactory for you.

5. The way of teaching listening skills involved in your curriculums was attractive.

6. The time allocated for studying listening involved in your curriculums was enough.

7. The listening skills involved in your curriculums have various activities and exercises.

8. The listening skills involved in your curriculums have various selections and videos.

9. The ways of teaching listening skills have various teaching aids.

10. The sound of the passages and conversations involved in your curriculums were clear.

11. The level of students was suitable for teaching listening skills.

12. Students have listening skills through teaching passages.

13. The subjects of listening were interactionally taught for students.

14. Teaching listening skills aligned with students' abilities and ages.

15. The way of teaching listening skills involved in your curriculums was suitable for students needs

16. The way of teaching listening integrated other language skills.

17.The ways of teaching involved in the curriculum have visualization and association.

18. The listening skills involved in curriculums included graphics, images, audios, and videos.

19. The presentation of content enhanced students' listening skills.

20. The visualization of passages and conversations involved in content were supportive.

Students stated that listening skills were too difficult for various reasons; listening skills need suitable materials to be studied. They could not use the selections without the aid of instructors and instructional aids as videos, data show, and visual passages. The topics of listening were so randomly organized. Most visual and auditory effects didn't suit the topics of listening. They 
confirmed that some visual effects were oldfashioned; others were full of excessive details. There are no visual effects for words that are far away from students' realization like old-fashioned tools or scientific equipment. On the other hand, instructors didn't use any aids for teaching listening selections to promote ideas and enhance learning. Most instructors expressed their dissatisfaction with learners having some weaknesses that sometimes-made difficulties for their students and instructors in the teachinglearning process. A good instructor is the one that can make learners assume that learning is an effective process. Listening content didn't take student's background knowledge into account. That, if happened, would help instructors tailor lessons to the specific attributes and interests of students. The listening level of the passages was too difficult so the student could not listen or understand new important information contained in the listening texts. They concluded their view indicating students 'inability to effectively listen. Besides, instructors provided inappropriate listening selections for their learners; they were unsuccessful to provide discourse ability, they almost failed to present idioms and new words involved in listening passages. There was no suitable content for them with different needs. There were no good topics that could be relevant for and interesting to all. Moreover, the used teaching methods prevented instructors' creativity. Listening selections didn't provide their own ability, and they may not be suitable for the level of learners in class.
They reported many difficulties with teaching listening. In particular, they noticed that some language skills were too difficult and advanced for their students, especially listening skills, the most important was that learners should feel that they have benefited from the lessons, and they can continuously listen in and out of the classroom.

\section{Discussion}

Students confirmed that listening skills were not studied permanently in their curriculums, as well as these skills were too difficult. some instructors had the same feeling about the curriculum. One of them said, "The listening skills need too much trainings, it should be related to the other language skills." There should be various teaching aids to be used by the instructor during the listening selections. Another student said "The listening skills are difficult and need much time to practice what we learn" this aligned with the study of Tyagi (2013) stated that listening skill is key to receiving messages effectively. It is a combination of hearing what another person says and psychological involvement with the person who is talking. Listening is a skill of language. It requires a desire to understand another human being, an attitude of respect and acceptance, and a willingness to open one's mind to try and see things from another's point of view. It requires a high level of concentration and energy. It demands that we set aside our thoughts and agendas, put ourselves in another's shoes, and try to see the world through that person's eyes. 
Some learners stated the following "Despite the difficult conditions that the world is going through during the study of curriculums, this hasn't developed my different skills (listening \& speaking) and it hasn't enabled me to communicate with my professors very well". Both students and instructors agreed that there are not enough tasks provided to promote the example or enhance these skills. Sometimes the listening activities are not adequate to students' abilities and developmental stage which causes the expertise reversal effect as Eltawila (2009) investigated the state of listening skills of (72) students. He assumed that English listening was still the overlooked or neglected skill in the program for preparing EFL instructors. Although these learners were preparing to become teachers of English, and although they had been exposed to from six to nine years of English instruction before this study, their proficiency in listening and speaking was perceived to be extremely low.

On the other hand, some instructors confirmed that teaching listening skills had too difficulties, it was too demanding and exhausting to both instructors and students; In this regard, an instructor stated: "I think it is not suitable for our students; it is complex and has difficult passages for them. The selections need to be revised to be more suitable". learners and instructors discussed listening skills should be studied in four years. One of the students said, "I also suggest that the listening skills should be in all specialize books, including passages and activities". In addition, this agreed with the study of Song (2008) concluded that foreign language majors often have difficulty handling listening tasks in an effective way due to inadequacy of listening strategies they were able to deploy.

The listening skills - in general - can help them to master other language skills as Chang and Millett (2019) provided some empirical evidence that L2 learners could benefit from the provision of additional support when doing extensive listening. Reading before (or while) listening can provide students with the necessary background knowledge of the input and reduce the number of unfamiliar linguistic elements, which in turn might enable learners to experience a higher level of comprehension. Finally, it is believed that frequent, successful, and enjoyable experience with listening may be a key factor that can motivate L2 listeners to further develop their listening fluency on their own, to listen more widely and independently, to use their listening skills to facilitate language learning and to acquire information and knowledge through listening.

Students need to be trained on many tasks this is aligned with study of Abdulrahman (2013) stated that teaching listening skills is one of the most difficult tasks for any ESL teacher. Sometimes they feel frustrated because students find problems and difficulties in listening process. Learners are trying to understand every word. they go back trying to understand what previous words meant. They didn't know the most important words. They don't recognize the words they know. Also, they have problems with different accents. They get tired and have a 
mental block. Also, they are distracted. So, they cannot cope without images. Students have hearing problems. According to Dunkel (2006), the language learner should develop certain listening skills such as predicting what the speakers are going to say and what the listening content will be about, ignoring and selecting information, taking notes, responding, comprehending the main ideas, and identifying the purposes of the speaker and the message. Instructors should improve and develop EFL majors' listening skills and functions to master the characteristics of effective listening and put them into effect toward effective oral communication.

Learners always complain of being unable to listen well in English when they are asked to do so. At the same time, their listening comprehension was poor; when they listened to English, they found it difficult for them to understand and identify a spoken passage. They were always shy, stressed, anxious, and unable to speak or listen. Despite the important role that encouragement and practice play in achieving the aims of any curriculum. This aligned with the study of Minhajul and others (2009) confirmed that the purpose of this study was to focus on the real scenario of listening skills at tertiary level in Bangladesh. It has been an effort to find out the reasons that are active behind students' poor listening skills. It has been observed that they carry out the poor listening skill from their primary and intermediate level to tertiary level and listening skill is not emphasized at any of these levels. So, it remains unattended throughout their academic life. As listening skill of English remains unattended in all phases of the EFL majors' educational journey, they lose interest in listening and gradually become a poor listener. It has also been identified that sometimes even language instructors do not give attention to listening skills and most of the time other skills are given priority over listening skills. So, students didn't feel any urge to improve their listening skills like other language skills.

Similarly, the listening skills didn't involve many activities to develop their thoughts for the third year Basic Education section. Maxwell (2016) confirmed that many times, learners let their thoughts wander rather than concentrating on what is being said. Sometimes, however, they listen too hard. Also, try to remember every word a speaker says, and they lose the main message by concentrating on details. Even when they think and listen carefully, learners usually grasp only half of what they hear, and they retain even less. improving your listening skills can be helpful in what steps can you take to overcome poor listening habits?

- Take listening seriously and commit to becoming a better listener.

- Work at being an active listener. Give your undivided attention to the speaker to understand his/her ideas.

- Resist distractions. Make a conscious effort to keep your mind on what the speaker is saying. Every part of your life, including speechmaking. The best speakers are often the best listeners. 


\section{Recommendations}

Results of the current study had several recommendations for both researchers and instructors that might help them improve teaching English as a foreign language. Theoretically, the study highlighted the success of the evaluative study in promoting instructional practices in foreign language settings. The evaluative study had all the potentials of establishing a rich environment for teaching four skills especially listening skills. Practically, the current research results showcased the urgent need for improving listening skills in different stages and for providing different kinds of feedback by learners together in groups and instructors with their students. Based on these results, a set of recommendations can be offered to EFL instructors, textbook, and program designers, and those involved in foreign language instruction, in general, to help solve the problems that constrain effective teaching and learning in foreign language instructional settings.

\section{- Recommendations for EFL instructors}

The evaluative study of listening skills was more likely to meet the different needs of language learners as it is more responsive to the remarkable variance in their learning styles. It addressed both their sensory and intellectual input, thus maximizing the likelihood that learners benefit from the different activities, instructional practices, and classroom chances made available to them in regular classroom settings. Instructors should be keen to improve their students' abilities accordingly. Establishing divergence and differentiation in classroom settings and beyond might be the key to future students' success in foreign language settings. Collaboration between instructors and students in the instructional process is a key to success in this regard.

The evaluative study of listening skills had similar potentiality to promote language learning outside classroom settings provided that students be better trained in adopting the model to their specific needs and professional expectations. Using the listening skills in such context would expand horizons and widen spaces for students to dig deeper and reach out to more abundance of knowledge and skills needed in their future professional careers.

The current study was concerned with listening skills. Yet, it is more likely to be effective in promoting other language skills and areas of concern to learners. Instructors are expected to use the evaluative study of listening skills in instructional practices pertinent to other language skills such as reading comprehension, writing for different purposes, oral communicative competence, and oral language production, to mention just a few examples. When functionalized properly within these settings.

\section{- Recommendations for textbook and program designers}

The current study had recommendations for textbook and program designers as well. Designing curriculums and developing language programs are the initial steps towards best practices in language teaching and learning. 
Existing curricula and language programs didn't fully meet the needs of students and instructors in foreign language settings. Numerous problems require due attention as it showed in the current study. For example, curriculum designers and foreign language program developers need to provide more flexibility and variance in content and methods of delivery. The one-size-fits-all view of textbooks and program development needs revisiting. Students have varying needs and expectations that can never be addressed using uniform content and instructional practices.

Creating balance and providing for variety apply not only to the kind of content and methods of delivery being developed but should also extend into language skills and areas. Most foreign language curricula and instructional programs miss the very point of properly striking a balanced emphasis on the different language skills. Some skills are sometimes overemphasized at the expense of other skills, which in turn results in deficiencies and inadequacies in students' language performance. All skills, listening is no exception, should be justifiably covered in foreign language curricula based on students' needs and professional expectations.

A similar problem arises when language curriculums and instructional programs disproportionately address lower and higher order thinking skills. Most often, higher order thinking skills receive less attention despite being instrumental in learning settings in general and foreign language settings in particular. As it had repeatedly been stressed, success can not emerge based on lower-level thinking and surface level processing of learning input. What usually makes the striking difference is the students' ability to dig deeper and manipulate language content in more creative and differentiated approaches. When students approach a task with more openness to divergence and variability, they achieve better and attain higher. This undoubtedly can't be achieved when assigned textbooks and proved curricula miss the very point of targeting higher level language processing for lower-level processing. Foreign language textbooks and program developers should pay due attention to this issue, should excellence in different foreign language learning settings be the target and ultimate outcome of foreign language programs.

\section{- Recommendations for foreign language instruction}

The current study also had some recommendations for foreign language instruction in general and that of the Egyptian context in particular. Foreign language instructors can benefit from this technique in order to educate more active students who gain direct experiences of expressing ideas by optimizing their entire ability and senses. The study gives students opportunities to clarify their values, realize, monitor, and modify their attitudes, and thus understand themselves in a better way.

Students' interests, learning styles, and ability levels should be taken into consideration in the teaching of listening skills. Learners are not only present in the classroom, but they can as well actively use all their modalities, which included 
somatic, auditory, visualization, and intellectual modality to construct their own understanding of the learning materials. They learn in co-operative ways, which in turn adds both fun and value to the learning process.

The nature of learning environment should be given due attention in EFL classrooms. Establishing effective classroom environments is instrumental for success in language classes. Effective environments in turn are often characterized by divergence, differentiation, variety, and equal chances for all those involved.

\section{References}

Abdalhamid F., 2012. Listening comprehension strategies of Arabic-speaking ESL learners. Master's Dissertation, Department of English, Colorado State University, Fort Collins, Colorado. Available online:

https://mountainscholar.org/handle/10217/65198.

Abedin M., Majlish S., Akter Sh., 2009. Listening skill at tertiary level: a reflection. The Dhaka university journal of linguistics, 2(3): 69-90. Retrieved from:

https://doi.org/10.3329/dujl.v2i3.4144

Abo El-kassem A., 2009. The effectiveness of using the storytelling approach in developing listening skills in English language for pupils of the preparatory stage (Unpublished master's thesis). Cairo University, Egypt.

http://library.iugaza.edu.ps/thesis/92124.pdf .

Ahmed W., 2014. Developing sixth primary students' English listening skills by using some authentic assessment techniques (Unpublished master's thesis). Suez Canal University, Egypt. http://main.eulc.edu.eg/eulc_v5/Libraries/Thesis/B rowseThesisPages.aspx?fn=PublicDrawThesis\&Bi $\underline{\text { bID }=12068944}$

Ainin M., 2020. Learning strategy patterns in developing skills for listening of Arabic speech. KnE Social Sciences, 4(4): 223-236. Available online:

https://doi.org/10.18502/kss.v4i4.6486.

Al-Ammary A., 2015. The effectiveness of a program based on podcasting in developing some EFL listening comprehension skills among preparatory stage students (Unpublished master's thesis). South Valley University, Egypt.

http://eulc.edu.eg/eulc_v5/Libraries/Thesis/Browse ThesisPages.aspx? $\mathrm{fn}=$ PublicDrawThesis $\& \mathrm{BibID}=1$ $\underline{2214310}$

Al-azzemy, A. F. T., \& Al-jamal, D. A. H. (2019). Evaluating cognitive, metacognitive and social listening comprehension teaching strategies in Kuwaiti classrooms. Heliyon, June 2018, e01264. Available on:

https://www.researchgate.net/publication/3327204 26 Evaluating cognitive metacognitive and soci al listening comprehension teaching strategies i n Kuwaiti classrooms. Retrieved on June, 10, $\underline{2020 .}$

Anderson M., 2018. The importance of listening. Available on:

https://ictevangelist.com/the-importance-oflistening. Retrieved on June 15, 2020.

Anderson M., 2018. The importance of listening. Retrieved on June 15, 2020. Available on: 
https://ictevangelist.com/the-importance-of-

listening.

Aryanaa Suhud \& Apasari Y., 2018. Analyzing Teacher's Difficulties in Teaching Listening. ELTIN Journal, 6(2), 100-106. Available on: http://e-journal.stkipsiliwangi.ac.id/index.php/eltin/article/view/1132.

Attia A. E., 2002. The effect of a strategy-based instruction program on developing EFL listening comprehension skills. $\mathrm{PhD}$ thesis, University of Warwick. http://wrap.warwick.ac.uk/3050/

Azmi B. M., Celik B., Yildiz N. \& Tugrul M. C., 2014. Listening comprehension difficulties encountered by students in second language learning class. Journal of Educational and Instructional Studies in the World, 4(4): 1-6. http://www.wjeis.org/FileUpload/ds217232/File/01 b.bingol.pdf

Barnard D., 2017. Active listening skills, examples and exercises. Available on:

https://virtualspeech.com/blog/active-listeningskills-examples-and-exercises. Retrieved on June, $\underline{10,2020 .}$

Barthes R., 2014. What is Listening Available online:

https://indritheresya.wordpress.com/2014/01/03/w hat-is-listening/

Baumeyer K., 2014. Effective listening: definition \& obstacles. (2014, May 20). Available on: https://study.com/academy/lesson/effectivelistening-definition-obstacles.html. Retrieved on May, 5, 2020.

Bress P., 2006. Listening Skills: What are they and how do you teach them. Modern English Teacher,
15 (1).42. Available online https://dialnet.unirioja.es/ejemplar/258216.Retriev ed on November 7,2018.

Brown S., 2006. Teaching listening. New York, US: Cambridge University Press. New York, NY 10013-2473, USA. Available on:

http://www.cambridge.org/elt/activelistening/pdf/T eachingListening.pdf. Retrieved on July, 10, 2020.

Brownell J., 2015. Listening: Attitudes, principles, and skills (subscription). Routledge. Available on https://www.google.com/books?hl=en\&lr=\&id=w R2aCgAAQBAJ\&oi=fnd\&pg=PP1\&dq=Brownell, +J.+(2016).+Listening:+Attitudes, + Principles,, and + +Skills+(Subscription).+Routledge, + New+York, + $\underline{\text { USA. } \& o t s=n m R X 1 I E a M O \& s i g=A c z 6 g K 1 U u R z g z}$ PN1 ZOyb7lm6FQ.

Burns A., Siegel J., 2017. International perspectives on teaching the four skills in ELT: listening, speaking, reading, writing. Retrieved from International Perspectives on Teaching the Four Skills in ... books.google.com.eg > books

Ciano K., 2014. Listening (definition, importance $\&$ effective listening) Available on:

https://www.slideshare.net/cianokevinjon/listening -definition-importance-effective-steps

Abdulrahman M., 2013. Listening skills teaching Published on Dec 18, 2013. Available online: https://www.slideshare.net/abammar/listeningskills-teaching.

Eltawila M., 2009. The neglect of listening activities among Egyptian preparatory school EFL instructors. ma thesis, school for international 
training graduate institute, Brattleboro, Vermont, USA. Retrieved from:

https://dlc.library.columbia.edu/catalog/ldpd:50104 2/bytestreams/content/content?download=true

Genaidy F., 2011. The effect of using students' journals on developing listening comprehension skills in English for the first-year secondary school students (Unpublished master's thesis). Helwan University, Egypt. Available online:

http://eulc.edu.eg/eulc_v5/Libraries/Thesis/Browse ThesisPages.aspx? $\mathrm{fn}=$ PublicDrawThesis $\&$ BibID $=1$ 1385258

Ghaderpanahi L., 2012. Using Authentic Aural Materials to Develop Listening Comprehension in the EFL Classroom. English Language Teaching. 5(6), 146-153. Available online:

https://files.eric.ed.gov/fulltext/EJ1079489.pdf.

Ghoneim N., 2013. The Listening Comprehension Strategies Used by College Students to Cope with the Aural Problems in EFL Classes: An Analytical Study. English Language Teaching, 6(2): 100-113.

Gilakjani A., and Sabouri N., 2016. "Learners' Listening Comprehension Difficulties in English Language Learning: A Literature Review”. English Language Teaching, 9 (6): 123-133. Available on http://dx.doi.org/10.5539/elt.v9n6p123. Retrieved from June, 10, 2020.

Gilakjani A., and Sabouri N., 2016. "The significance of listening comprehension in English language teaching". Theory and Practice in Language Studies, 6 (8): 1670-1677. Available on: http://dx.doi.org/10.17507/tpls.0608.22. Retrieved on June, 10, 2020
Goh C. C. M., 2000. A cognitive perspective on language learners' listening comprehension problems. System, 28: 55-75. Available online: https://repository.nie.edu.sg/handle/10497/18662

Gonen M., 2009. The relationship between FL listening anxiety \& FL listening strategies: The case of Turkish EFL learners. Proceedings of the 5th WSEAS/IASME International Conference on Educational Technologies, July 1-3, 2009 (pp. 4449). University of La Laguna, Spain. Available online: https://www.semanticscholar.org/paper/therelationship-between-fl-listening-anxiety-andGonen/3a824668c9510d2bec1e921d6e430ecc0003 f1a9

Graham S., Santos D., 2015. Strategies for second language listening. Retrieved from Individual Differences in Early Language Learning: A Study … books.google.com.eg > books

Guo J., 2015. Inference-Making and Linguistic Skills in Listening Comprehension: An Observation of French Students Learning Chinese. Electronic Journal of Foreign Language Teaching, 12(1): 318-331 Available from: https://pdfs.semanticscholar.org/899d/b3ee1f47774 3dbdfcd465f40a9ccda9cbc0e.pdf . Retrieved on November, 7, 2018.

Haladyna T. M., Downing S. M. \& Rodriguez M. C., 2002. A review of multiple- choice itemwriting guidelines for classroom assessment. Applied Measurement in Education, 15(3): 309334. Available online:

http://www.specialconnections.ku.edu/.

Jafari K. \& Hashim F., 2015. Comparison of Normal and Moderately Slow Speech Rates: 
Listening to Students' Voices in Listening Comprehension Classes in EFL Context. International Journal of Foreign Language Teaching in the Islamic World, 3(3): 5-11. Available online:

https://scholar.google.com/scholar?cluster=213786 2574930333728\&hl=en\&oi=scholarr

Khoiriyah K., 2020. Call and Sla theory: Developing a framework to analyze web-based materials for teaching listening skills. ideas: Journal on English language teaching and learning, linguistics and literature, 8(1),80-92. Available online:

https://ejournal.iainpalopo.ac.id/index.php/ideas/ar ticle/view/1296/0.

Makayev K., \& Makayeva G., 2019. Listeningreacting ability as one of vital activities for training spontaneous communication skills. In Edulearn19 proceedings 11 th international conference on education and new learning technologies palma, spain. 1-3 july, 2019 (pp. 1957-1962). iated academy. Available online:

https://dialnet.unirioja.es/servlet/articulo?codigo $=7$ 462067.

Maverick M., 2019. Listening skills importance: types and benefits of developing effective listening skills. Available on:

https://www.myknowledgehunt.com/listeningskills-importance-and-types. Retrieved on June, 10, 2020.

Metruk R., 2019. Using English movies and TV programs for developing listening skills of EFL learners. Information technologies and learning tools, 70(2): 227-236. Available online: https://scholar.google.com.eg/scholar?hl=en\&as s $\mathrm{dt}=0 \% 2 \mathrm{C} 5 \&$ as_vis=1\&q=Metruk\%2C+R.+\%2820 19\%29.+Using+English+movies+and+TV+progra $\underline{\mathrm{ms}+\text { for+developing+listening+skills+of+EFL+lear }}$ ners.+ISSN\%3A+2076-

8184.+Information+Technologies+and+Learning+ Tools $\% 2 \mathrm{C}+2019 \% 2 \mathrm{C}+\mathrm{Vol}+70 \% 2 \mathrm{C}+\% \mathrm{E} 2 \% 84 \% 9$ 62.\&btnG=

Mohajer, S.\& Pourgharib, B. (2014). "The effect of captioned videos on advanced EFL learners' listening proficiency in Iran”. International journal of basic sciences \& applied research, 3 (12): 951957. Retrieved on June 22, 2020. Available on: http://isicenter.org/fulltext/paper-352.pdf.

Moulesong B., 2010. Listening skills are an important part of effective communication Available on:

https://www.nwitimes.com/business/jobs-andemployment/listening-skills-are-an-important-partof-effective communication/article b4d0940af919-5d1a-be45-05da2c6752c2.html. Retrieved from June 10, 2020.

Mulvania P., 2019. The importance of active listening. Available on:

http://www.giftoflifeinstitute.org/the-importanceof-active-listening. Retrieved from June, 10, 2020.

Nowrouzi S., Tam S. S., Zareian G., \& Nimehchisalem V., 2015. Iranian EFL Students' Listening Comprehension Problems. Theory and Practice in Language Studies, 5(2): 263-269. Available online.

Osada N., 2004. Listening comprehension research: A brief review of the past thirty years. Dialogue, 3(1): 53-66. Available online: 
http://www.academia.edu/9957789/Listening Com prehension_Research_A_Brief_Review_of_the_Pa st_Thirty_Years

Pham P., 2017. A study on difficulties and solutions in English listening skill of the secondyear students in Faculty of Foreign Language at UTEHY Published on Jun 12, 2017. Available online:

https://www.slideshare.net/phamphi95/a-study-ondifficulties-and-solutions-in-english-listening-skillof-the-secondyear-students-in-faculty-of-foreignlanguage-at-utehy

Pourhosein A., 2016. Learners' Listening Comprehension Difficulties in English Language Learning: A Literature Review. Published by Canadian Center of Science and Education available on:

http://dx.doi.org/10.5539/elt.v9n6p123 Retrieved on May, 5, 2020.

Rost M., 2002. Teaching and Researching Listening. London: Longman. Available online https://books.google.com/books?hl=en\&lr=\&id=xq EuAgAAQBAJ\&oi=fnd\&pg=PP1\&dq=Rost,+ M.+ (2002).+Teaching+and+Researching+Listening. $+\mathrm{L}$ ondon:+Longman.\&ots=CkUAsnWHSf \&sig=sXR hrqEgK8-gKAZL8Gd86KqJWrU

Rost M., 2009. Teacher Development Interactive: Listening. White Plains. NY: Pearson Longman. Available online:

https://windsor.my/teacher-developmentinteractive-tdi/

Ruzicki C., 2014. Strategy-based listening and pragmatic comprehension. Brazilian English Language Teaching Journal, 5(1): 4-14. Available online:

http://revistaseletronicas.pucrs.br/ojs/index.php/bel t/article/view/18090/0

Sandelowski M., 2000. Whatever happened to qualitative description? Research in nursing \& health, 23(4): 334-340.

https://onlinelibrary.wiley.com/doi/abs/10.1002/10 98240X(200008)23:4\%3C334::AID-

\section{NUR9\%3E3.0.CO;2-G}

Sebongbong R., 2019. Definition of listening skills. Available on:

https://idoc.pub/documents/definition-of-listeningskills-6nq88rwxqqnw. Retrieved from May, 11, 2020.

Shahbaaz A., 2014. Improving your listening available on skills! Available on:

https://www.slideshare.net/shahbaazahmed15?utm _campaign=profiletracking\&utm_medium $=$ sssite \& utm_source=ssslideview. Retrieved on May, 5, 2020.

Taghinezhad A., Tabaeifard J. \& Bazyar Z., 2015. Investigating the impact of teaching listening comprehension strategies on the improvement of listening comprehension ability of Iranian EFL learners. International Journal of English Language, Literature, and Translation Studies, 2(3): 397-403. Available online:

https://www.researchgate.net/publication/2817810 83 investigating the_impact_of_teaching_listenin g_comprehension_strategies_on_the_improvement _of_listening_comprehension_ability_of_iranian_e fl_learners.

Third J., 2019. Five practices for better active listening available on: 
https://www.hallaminternet.com/become-betteractive-listener. Retrieved from May, 6, 2020.

Tiret H., 2015. The importance of listening skills. Available on: https://www.canr.msu.edu/news/the importance of listening skills. Retrieved from June, 10, 2020.

Trabajo (2012). The importance of teaching listening and speaking skills. Retrieved from https://docplayer.net/23444148-The-importanceof-teaching-listening-and-speaking-skills.html

Tyagi B., 2013. Listening: An important skill and its various aspects. The criterion an international journal in English. 12, 1-8. Available on http://www.the-criterion.com/V4/n1/Babita.pdf.

Retrieved from June 10, 2020.

Ulum Ö. G., 2015. Listening: The ignored skill in EFL context. Online Submission, 2(5): 72-76. Available on:

https://files.eric.ed.gov/fulltext/ED577306.pdf.

Retrieved from June, 10, 2020.

Usman 2015. Communication skills listening and speaking skills Available on:

https://www.slideshare.net/usmancp2611/communi cation-skills-listening-and-speaking-skills.

Retrieved on June, 11, 2020.

Usó-Juan, Martínez-F 2008. Current trends in the development and teaching of the four language skills. Retrieved from Current Trends in the Development and Teaching of the four Language Skills - books Google
Vandergrift L., \& Goh C. C. M., 2012. Teaching and learning second language listening: Metacognition in action. New York, US: Routledge. Available on:

http://www.scielo.org.co/scielo.php?script=sci_nli $\underline{\text { nks } \& \text { pid }=\text { S1657- }}$

$\underline{0790201800020016100032 \& \operatorname{lng}=\text { en. Retrieved on }}$ June, 10, 2020.

Vandergrift L., \& Tafaghodtari M. H., 2010. Teaching L2 learners how to listen does make a difference: An empirical study. Language Learning. Available online:

http://dx.doi.org/10.1111/j.1467-9922.2009.00559

Wah N. N., 2019. Teaching listening skills to English as a foreign language student through effective strategies. International journal of trend in scientific research and development (IJTSRD), 3(6). Available online:

http://www.academia.edu/download/61285798/146 Teaching Listening Skills to English as a For eign Language Students Through Effective Stra tegies20191120-36706-71d2rk.pdf.

Wong J., 2014. The importance of good listening skills. Available on:

https://prezi.com/uuzwdiwpdl0k/the-importanceof-good-listening-skills. Retrieved on June, 10, 2020.

Yavuz F., 2015. Problems and Activities in Listening Skills in EFL classrooms: from Tradition to a more Comprehensible Input. Procedia. Available online:

https://cyberleninka.org/article/n/875663 